UCRL --15870

DE87 004319

\title{
FINAL REPORT \\ Research on the Climatic Effects of Nuclear Winter
}

\author{
Robert E. Dickinson
}

\section{Submitted by}

National Center for Atroouphetic Resareh

Boulder, Colorado

Centrat Nó. SF/220:

SANL 400-001

December 3, 1986

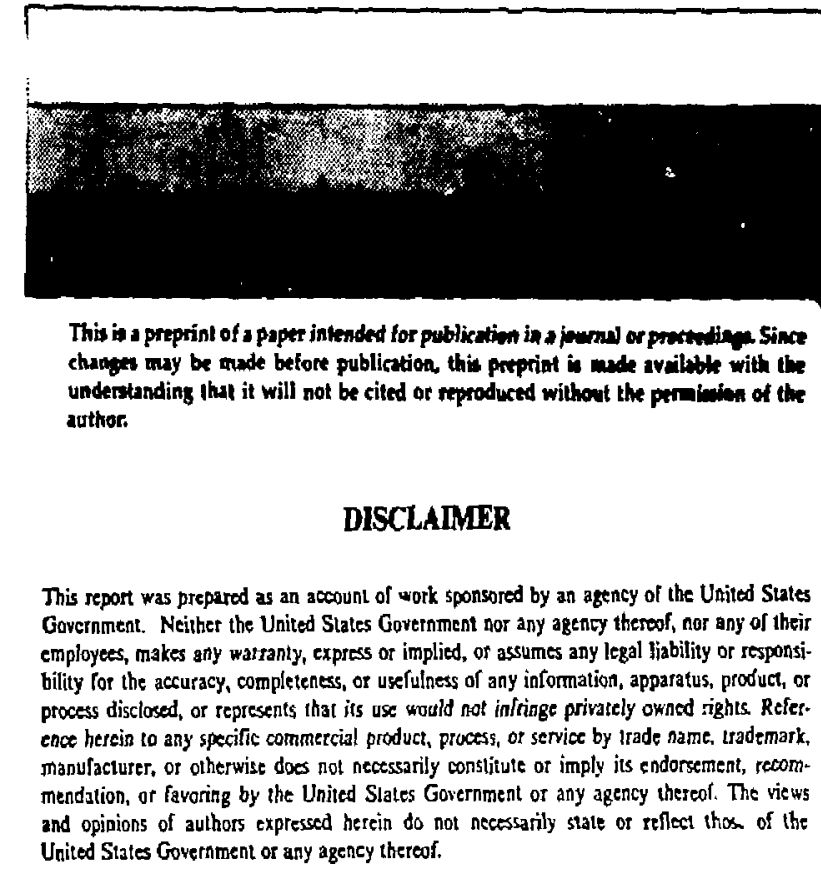


FINAL REPORT

Research on the Climatic Effects of

Nuclear Winter"

\author{
Robert E. Dickinson
}

\title{
OVERVIEW
}

Since beginning work on this contract in early 1984, the National Center for Atmospheric Research (NCAR) has undertaken a series of research efforts to develop and implement improvements to the Community Climate Model (CCM) needed to make the model more applicable to studies of the climatic effects of nucleas war. These studies were done, in most cases, to augment and complement engoing NCAR reseasch activities.

As of this date, the development of the model improvements has reached a stage where implementation may proceed, and several of the developed routines are now being incorporated into the next approved vertion of the CCM (CCM1). Formal documentation is now being completed describing the specific model improvements that have been successfully implemented.

This final report includes ps attechments the series of annual proposals and progress reports that have guided the project. Formal documentation of the activities and accomplishments is presented in the series of reports listed in the attached set of publications.

- This work was prepared under the auspices of the U.S. Department of Energy by the Lawrence Livermore National Labortory under contract W-7405-Eng-48. 


\section{ATTACHMENTS}

1. SANL 306-011 and overall work statement, dated May 21. 1984.

2. NCAR Proposel 84-4.1, dated July 1984

3. Letter progress report for FY84 from R.E. Dickinson, dated Sept. 7, 1984.

4. Letter progiess report for FY.85 from R.E. Dickinson, dated March 21, 1985

5. NCAR Proposal 84-4.2, dated August 1985

6. Letter progress report clarifying NCAR Proposal 84-4.2 from R.E. Dickinson, dated October 25, 1985.

7. Letter progress report for FY-86 from R.E. Dickinson, dated May 2, 1986

8. Letter final report from R.E. Dickinson, dated December 3, 1986.

9. List of publications and reports. 


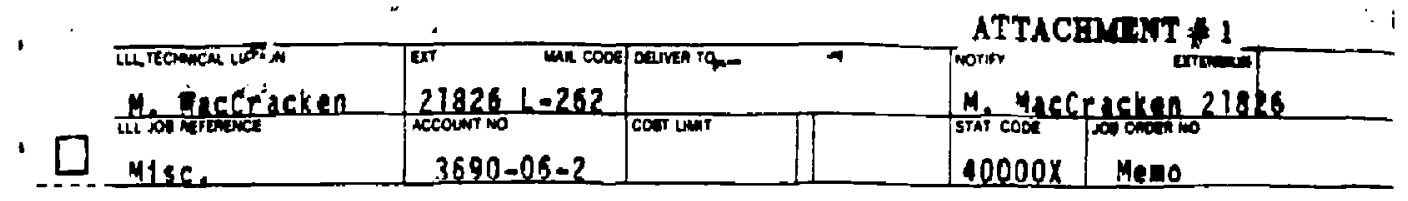

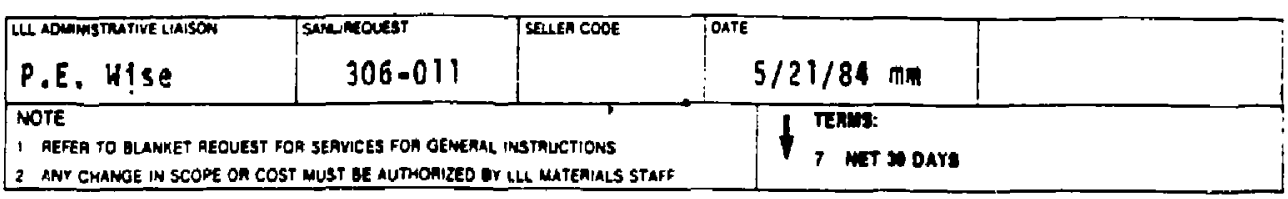

UT.S. DOE - SAN (DOE/SRN)

internal olstribution Only

SMIR To

No Recelvais Expected at LLNL
UNIVERSITY OF CALIFORNIA

LAWAENCE LIVERMORE NATIONAL LABORATORY

3PECIA MATINIALS OFFICE winonawou moutar

ron contanct no wiratemo 4 wTh the cepantulnt of enenar wh noret in threlcate to unvinerty or calromen LAWHENCE LIVERMOAL WATIONAL LABORATOAY Accounting Othes - Dox 5001 Uurermon. Callomis Msso

\begin{tabular}{|c|c|c|c|}
\hline 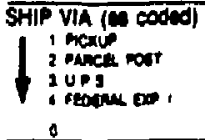 & 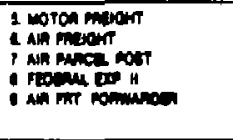 & 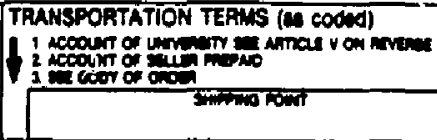 & 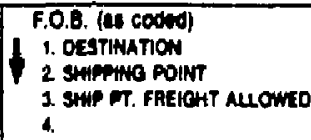 \\
\hline int & OLSCAPTION & Ounitrit ! & \\
\hline
\end{tabular}

Thts SANL is 1ssued to the Mational setence fioundation (USF) to support the rork whtch will be conducted for (LAL by the National center for Atmospherlc Ressarch (ICAR) under oot Interagency Agreenent Ho. OE-A103-84SF $1220 B$.

An Interagency Agreenent has been esthbllshed for th1s work. The work performed by MCAR wtll be for develophent on and application and dequisttion of the Community climate fodel. This model is to be improved in ways that will permit both institutions to use the nodel as part of their research orograns into the global-sede atnospherte effects of nuclear exchange and other programatic studies as deseribed in the "Work Statement".

The LLNL cost estinate on the above work is \$50,000,00 for Fr84. The total LLML cost estinate on the above work ts $\$ 650,000.00$; however. onl! $\$ 50,000.00$ is being released at this time. The renatning $\$ 600,000,00$ w11 be released for work to be done in FY85 and FY86. The perfod of performence will be for the perfod ending Septembar 30, 1986. The work is beting funded by the Atmospherte and Geophystcal Sciences Oivision.

MSF Contacts: Aaron Asrael and llene Bute. HCAR Administrative Contact: Davfo Haltman NCAR Techntcal Contact: Stephen Schnolder

The agreement was placed with: National Sclence Foundation Attn: Contracts and Grants Aaron Asreal/llene Bute 1990 G St.. Y.W., Roon 644 Washington, D.C. 20550

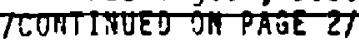


LLNL and NCAR herewith undertake to improve the Community Climate Hodel (CCM) in ways that will permit both institutions to use the model as part of their research programs into the glocal-scale atmospheric effects of a nuclear exchange and other programmatic studies.

\section{Model Development to be Undertaken by NCAR}

CCM studies of tha global effects of a nuclear exchange have indicated a number of areas requiring improvements to the model if an accurate physical representation of important processes is to be achieved. These areas include:

1. Radiative transfer. The radiative transfer package presently in the CCM does not allow for incorporation of scattering aerosols such as nuclear war generated smoke or dust. It is proposed to develop a new radiative transfer capability for use in nuclear war/climate studies and other important aerosol/climate problems (e.g., volcanic dust, cloud droplets). A primary goal would be to incorporate a highly modular packaze having much improved flexibility for all types oi atmospheric radiative transfer problems and the capability of easy modification. The programs would be tested in one-dimensional models before inclusion in the general circulation model. It is anticipated that this work would take 2 to 3 years.

2. Planetary boundary layer and surface processes. The calculation of transients in surface temperature is crucially important in general circulation model studies of the nuclear war/climete problem. The present CCM includes only a crude zero heat capacity land surface and no explicit planetary boundary layer (PBL) parameterization. The importance of the correct simulation of low-level cloud and/or radiation fog formation to the surface temperature transients must be studied using more detailed parameterizations than are presently incorporated. A combination PBL parameteriation and improved surface physics package must be included in the $\mathrm{CCM}$ before the detailed time and space evolution of surface temperature can be reasonably trusted. The improverients would be tested with the diurnal solar cycle. Work would take about 2 years.

3. Sub-grid scale vertical convection. Nuclear smoke will be transported vertically by convection as well as by large scale motions, especially in the intensely heated upper regions of smoke clouds. The sub-grid seale parameterization of convection used in the CCM is a simple convective adjustnent, which does not allow for movement of any quantity other than moist static energy. An improved convective parameterization that explicitly includes vertical mass and moisture flux must be specifically included in order to simulate the vertical movement of smoke. Work would take about 2 years. 
4. Tracer transport and removal. The three-dimensional advection and removal of smoke and dust must be included in any comprehensive simulation of the nuclear war/climate problem. At present there is no capability in the CC: of doing this. An improved hurizontal advection scheme for high-gradient tracers is needed because the present advection in spectral space is known to have serious defieiencies. Moreover, the transiormation, coagulation, sedimentation and scavenging of aerosols is a difficult microphysical problem that will no doubt require successive generations of parameterizations of increasing refinement. Little is known about how a three-dimensional GCM will react to a strongly radiatively active patchy tracer substance. For this reason crude preliminary tracer simulations should also be performed, perhaps using the present spectral formulation, in order to develop intuition about model behavior and to attempt to uncover any model problems that may need attention before detailed tracer studies can be performed. Since LLNL is developing a tracer nodel that can be synchronously coupled to the $\mathrm{CCM}$, support from this contract will be mainly to assure that a comparison can be made with the internally calculated CCM tracer transport capability to be developed separately by NCAR.

LLNL funding would be combined with NCAR and other funding to provide for personnel and necessary computer resources for model improvements in each of these areas. Emphasis in model improvement would be as follows:

FY-84: Task 2

FY-85: Tasks 1, 2, 3

FY-86: Tasks 1, 3, 4

\section{Transfer of Improved Subroutines to LLNL}

LLNL will provide the resources necessary to tranfer the version of the CCM to be used by NCAR in these studies to the LLNL computer system. The version of the $\mathrm{CCM}$ to be transferred and associated processing routines are currently available from NCAR (and possibly other sources) and transfer to LLNL is expected to begin in the spring of 1984 .

Model application studies will be conducted by both LLNL and NCAR as part of their respective programs. As part of this contract, NCAR will provide available documentation and magnetic tape copies of the improved subroutines for use in the CC.M upon completion of initial testing of the subroutines. Adaptation of the codes to the LLNL computer system wili be the responsibility of LLNL personnel, with NCAR to provide advice in response to specifie inquiries.

\section{Wodel Application Studies with the CCM at LLNL}

Use of the CC:M to investigate the consequences of a nuelear exchange will be undertaken by both LLNL and NCAR as part of their own programs. This contract does not restrict either organization in any way from conducting such model studies.

In addition, joint model studies may be provided for under this contract by the LLNL technical contact and the NCAR co-prineipel investigators, particularly when CC.H model improvements made as part of this contract are first used in verification and application studies. 


\section{Other Contract Provisions to be Included}

1. All model improvements made by NCAR under this contract shall be freely available to both NCAR and LLNL for use in other models a vailable at their institutions.

2. All work done under this contract will be unclassified.

3. All model improvements and developments and all joint application studies may be published by either institution, subject to (1) normal internal scientific peer review procedures of the institution(s) of the author(s); (2) official patent, classification, and contract review procedures.

4. For joint model studies done at LLNL, LLNL will provide computer time and office support for visiting NCAR personnel. For visits of LLNL staff to NCAR, NCAR will provide office support.

\section{Contraci Term and Expected Approximate Funding Level}

The contract is to cover the period FY-84 to FY-86, with each extension beyond the first year subject to annial re-approval by each institution. From preliminary discussions funding is estimated as follows; an official cost breakdown to be submitted by NCAR.

\begin{tabular}{lrrr} 
& FY-84 & FY-85 & FY-86 \\
\hline Personnel (incl overhead) & 25 & 215 & 185 \\
Consultants/Travel & 5 & 5 & 5 \\
NCAR Computer Time & $\frac{20}{50}$ & $\frac{80}{300}$ & $\frac{110}{300}$ \\
Total & & \\
\hline
\end{tabular}

\section{Project Objectives by Year}

FY -84: Selection of improved PBL/surface parameterization. Initiate transfer of CCM and associated input/output codes to LLNL computer system.

FY-85: Implementation and testing of improved PBL/surface parameterization.

Development of new radiative transfer package for CCM.

Development of new convective prescription that specifies air mass and moisture fluxes.

FY-86: Implementation and testing of new radiative transfer package. Implementation and testing of new convective prescription. Application studies with improved CCM.

Distribution

II. Hay, L-19

J. Nuckolls

J. Knox

R. Perret, L-8

J. Penner 


\title{
NATIONAL CENTER FOR ATNOSPHERIC RESEARCH
}

P. 0. Box 3000 - Boulder, Colsrado 80307

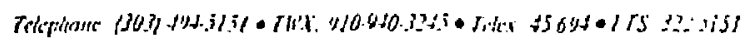

\section{December 1983}

\author{
Drs. Michael MacCracken and Cecil Leith \\ Lawrence Livermore Hational Laboratory \\ L-13, P, O. BOX 808 \\ Livermore, CA 94550
}

Dear Nike and Chuck:

I enjoyed our meeting at Livermore on Dec. 6 and the chance to have Starley Thompson, Jeff Kiehl, V. Ramaswamy and I show you our early modeling results in the study of potential climatic effects of sroke and dust veils generated by hypothetical nuclear var scenarios. This letter follows up on your request to me at our Dec. 6 meeting to present a brief overview of how MCAR scientists could, with some help from Lawrence Livernote National Laboratory, enhance the capability of one present version of the MCAR Community Climate bodel (CCNOB) to tore reliably simulate nuclear smoke and dust aerosols. Since our meeting and the presentations rade at the AGU session the following day, we have held many internal meetings and written several draft plans. Tnere have been wide discussions by merbers of the Climate Section, the CCI core group, the COM steering comnittee, and the Advanced Study Program. Also involved in these discussions have been the AAP Director, the Director of NCAR, the President of UCAR, and Gene Bierly of the NSE. We have developed an outl ine of a comprehensive NCAR progran to enhance the $\mathrm{CONOB}$ for applications to climate change experiments in general, and nuclear war jerosols in particulat. The progran would focus on mojel development in areas that are particularly critical to surface climatic response to radiative perturbations, sub-grid scale vertical transport of energy and wass in the boundary layer and free atmosphere and on transport and removal of aerosols (sae Attactment A). NCAR is willing to support a considerable frattion of this effort through the continuing contribucion of scientific staff, prograners and conputer time. However, rapid progress in the schedule of COM enhanceraent for the nuclear war/climate problem will require outside funding of scientifis staff, computer time and equipment. In particular, we will need help from LLNL to support the addition of experts in the first three scientific areas on Attachent $A$ (i.e., $r$ adiative transfer; planetary boundary layer and surface processes; and sub-brid scale vertical convection) as well as for computer time.

Very roughly, in FY84 we estimate the need for LLiL support of 0.25 FTE ior a Scientist I level position in planetary boundary layer hus' (S.L. Thompson) as well as 0.05 FTE for a senior scientise (R.E. 
Dickinson). ACAR would contribute toughly 0.25 and 0.10 : IE respectively to support these scientist s' work on CCM development releveat to nuclear war/climate studies. Managenent, travel and computer $t$ itne requests (about 10 CCUs) would bring the LLNL FY84 share to approxinately $\$ 50,000$.

For each of FYBS and FY86, the following are tentative examples of NC.AY and iLNL cost sharing;

\section{Propesed Funding in FY85 and FY8ó (tentative examples)}

\begin{tabular}{ll} 
Personnel & ETEg \\
\hline Junior-level scientists & 1.5 \\
Senior-level scientists & 0.5 \\
Yanagement & 0.1 \\
Programing & 1.0 \\
Secretarial & $\underline{0.2}$ \\
& 3.3
\end{tabular}

Personnel cost including benefins and overhead: about $\$ 200 \mathrm{~K}$ per year.

Cray-l computer resources (about 150 low-priority CPU hours per year for model development): about $\$ 100 \mathrm{~K}$ per year.

Total LLiL funding: about $\$ 300 \mathrm{~K}$ per year.

\section{ICAR comitment}

NCAR would more than match LLML's support of wodel enhancenents by its COS development efforts by the equivalent of $\$ 400 \mathrm{~K}$ per year in FY85 and FY86. (E.g., the \$100R funding by LLKL for Cray-1 time represents less than half of the resources that will be required for model development and control runs,) NCAR will seek outside funding from additional sources to cover a portion of this expanded effort.

These examples are, of course, preliminary estimates in very round numbers. We look forward to your reactions to them. We would be very heppy to provide a more formal and detailed proposal of our plans once we ve received your remarks on the research.

With regard to management and scientific direction, Bob Dickinson and I have agreed to be co-principal investigators of any outside proposals. Scientific consultation fron senior members of the XCAR Climace and large Scale Dynamics Sections would also help to maintain the scientif:e quality of new modil development efforts. Final atrangements, however, between NCAR and LLNL would, of course, have to be approved by the NCAR Director, appropriate NSF managers, and eppropriate LLill officials. 
I hope you find this letter responsive to your original request, and look forward to your response.

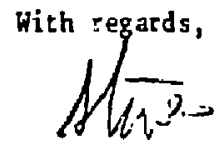

Stephen H. Schneider

Deputy Dicector,

Advanced Study Progran

SHS:bro

att achment

cc: R. Anthes

R. Dickinson

W. Hess

S. Thompson

W. Washington 
1. Radiative transfer. The radiat ive transfer package presently in the COM does not allow for incorporation of scattering aerosols such as nuclear war generated swoke or dust. It is proposed to develop a new $r$ adiative transfer capability for use in nuclear war/climace studies and other important aerosol/climate problems (e.g., volcanic dust, cloud droplets). A primary goal would be to iscocporate a highly modular package having much improved flexibility for all types of atrospheric radiative transfer problems and the capability of easy modification. The prograns would be tested in one-dimensional models before inclusion in the general cir.ulation model. It is anticipated that this work would take 2 to 3 years.

2. Planetary boundary layer and surface processes. The calculation of transients in surface temperature is crueially important in gener al circulation model studies of the nuclear war/ciimate problem. The present CCA includes only a crude zero heat capacity land surface and no explicit planetary boundary layer (PBL) paraneterization. The importance of the correct simulation of low-level cloud and/or radiation fog fornation to the surface temperature transients must be studied using more detailed parameterizations than are presently incorporated. A conbination PBL parameterization and inproved surface physics package must be included in the COI before the detailed time and space evolution of surface temperature can be reasonably trusted. The improvements would be tested with the diurnal solar cycle. Hork would take about 2 years.

3. Sub-grid scale vertical convection. Nuclear swoke will be transported vertically by convection as well as by large scale motions, especially in the intensely heated upper regions of smoke clouds. The sub-grid scale parameterization of convection used in the COM is simple convective adjustment which does not allow for movement of any quanticy other than moist static energy. An improved convective parameterization that explicitly includes vertical mass flux must be specifically included in order to simulate the vertical movement of smoke. Work would take about 2 years.

4. Tracer transport and removal. The three dimensional advection and removal of swoke and dust must be included in any comprehensive simulation of the nuclear war/climate problem. At present there is no capability in the $\mathrm{CCM}$ of doing this. An improved horizontal advection scheme for high-gradient tracers is needed because the present advection in spectral space is known to have serious deficiencies. Hoceover, the transformation, coagulation, sediment at ion and scavenging 
of aetosols is a difficult microphysical problem that vill no doubt require successive gennrations of parmeterizations of increasing refinement. Little is known about how a three-dimensional GCY will react to a strongly :adiatively active gatchy tracer substance. For this reason crude preliminary tracer simulations stould also be perforted, perhaps using the present spectral formulation, in order to develop incuition about model behavior and to attempt to uncover any model problems that may need attention before detailed tracer studies can be perforned. Since LLNL would use a separate tracer model developed in-house, LLil would Lot be expected to support the developrent of tracer capabilities in the CCM.

5. High-Resolution CFM Stridies. It would be desirable to perform simulations with a high-resolution (around $100 \mathrm{~km}$ ) model in order to test the sensitivity of the results of nuclear smoke simulations to model resolution. Such simulations could more accurately depict transient smoke sources and smoke movement and diffusion than standard model tuns. They also sould be use ful in checking the resolution dependence of rainfall removal processes by more direct sigulation of mesoscale rainfall and the possible iufluence of mesoscale circulations generated along ragke boundaries. The length of the simulations would have to be relatively short to ayoid excessive computer resour:e use. This effort could be conducted with the NCAR mesoseale model nested vithin the Community Forecast Model (CFM) and conducted with the Regional Acid Deposition Modeling Project. 
KCAR Fopoenl b. B-4.1

\author{
a colringertos \\ ar \\ RESENGCH OA ChDATIC ETRETS \\ or \\ NUCLEAR WAR \\ "con mankerart" \\ to be carried oat by war \\ with eupport tron the \\ Dephrowirs or misher \\ tor
}

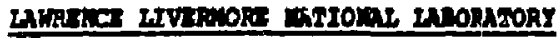

\author{
Principal Iuvestigtors: \\ Bobert E. Diteklneon \\ and \\ stepinen a. abmolder
}

Juliz 1984 
COY BIHAKCEMETI

Ao an update of hear proposal 184-4 subnitted last January for FYB4, this letter describes the groposed PY85 effort that NaR is asking Lawrence Wversore totional Laboratory to support to apeed up the developmant of the comminity Clicat v tol (CCH) parameterizations needed to improve projections of the clinatic effecte of nuclear var. The proposed wrk is to be carrled out Whin the itaspheric malysis and Prediction Division of scar. A rejated grant fron the Defenue

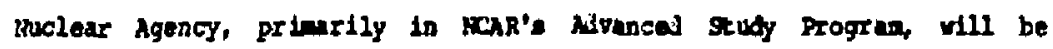
supporting related atudies of the clinatic effect of nuclear var.

The wrk proposed here wll be only a fraction of RaR's totul effort devoted to linproving the $\mathrm{Con}$ and to studying the climatis effects of nuclear war. Bowever, it should contribute ignificantly to both objectives. We are already comitted to aking avallable to the general comminity of cos users nodel ingovents in fhysics and code structure after they hare been adoquately tonted and studied by their originatora. Trough collaborative work and close coanunication, Lurence Iipermore scientiets all be wong the flrot of outside users to obtain inpropeante that would increase our confidonce in sirulations of clinate change resulting fron auclear war.

The following is a description of the tusks, porsonnel, and

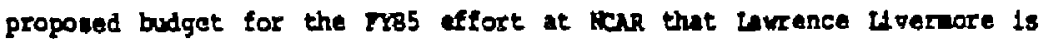
being asked to support. vill be happy to provide brief letter 
reports on about a three-month basis after the requested funds have been provided to XCAR and to report by phone whenever any significant new developments occur. Punding for future years will be essentially at this same level.

1. Planetary bomdury laper, sarfece proceases, and Ipleneatution of a diumal cycle (continas pust propowed work) (R. Dicleseos, P. Imasy)

A Eimple PBL wodel has been doveloped. It $\$ \leq 11$ be further tested Including the effect of adding wore layern to the lowest model levels. Computer code for a diurnal cycle vill be mohed with the exinting radiation package. A dotalled surface phyolce paranoterization, now in the process of being linked to the $\cos$, wll be further tested for errors and used in som sinulations to idontify posalble defects. Wh will start to collect and incorporate into the con murface property data sets required by the surface phyelcs paranteriations.

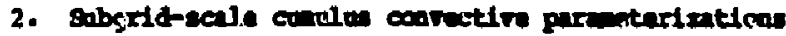
(2. Domner)

Various cumulus paraneterizations w11 be developed and tested In the COM. Tiese paraneterizations will provide estimates of the vertical redistribution of hent and soisture. Their spplication to vertical transport of mowentu and same wll also bo constdered.

\section{Inrgo-scale moistare traneport paranterientioe (P. Iasch)}

One of the serioul curront defects in the $\cos$ is its treatment of water vapor, especlally in high latituden where, in spite of assive "filling," large regions of negative nixing ration are still obtalned. A number of different transprt schenes besides that now being used will be incorporated into the con and tested. 
4. Docenatitios of radiation code (J. Eehl)

One of the sost difficult aspects of the con for outside users to work with is the radiation and cloud subroutines. These are very complex and not coded in a form conpatible with the rest of the code. Pecoding of the existing routine 1nto the standard cal form is not now posuible because of lack of code documentation. A report documenting the radiation code w1ll be completed as a nocessary proliminary step before 1eproved radiation paramoterfations can be developed and provided to outside users.

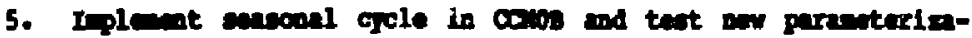

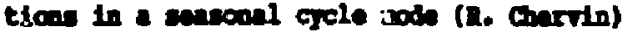

The now standard supported COA verston (CONOB) is only sat up to do either perpetual Janury or July inulations. For wost el lmate studies, seasonal cycle simulatione allow sore confidence in the resul to obtalned. To inpleant a seswonn cycle requires codifications in the radiation routine and organization of duta sots for sea ice, ccean surface temperature, and ovone path lengths. 
Fer sonnel and Budyet Breakdown

\section{SALARIES}

\begin{tabular}{|c|c|c|}
\hline Effort & & $s$ \\
\hline 0.20 & $\$$ & 9,000 \\
\hline 0.25 & & 16,300 \\
\hline 0.20 & & 6,000 \\
\hline 0.20 & & 7,400 \\
\hline 0.20 & & 6,800 \\
\hline 0.20 & & 6.000 \\
\hline 1.25 & & 51,500 \\
\hline
\end{tabular}

BETETITS $(24.50)$

12.600

subtotal:

64.100

MATRIAL \& SUPPLIES

600

PURCEASED SERVICSS (postage, 1,000 communication, atc.)

TRAVEL 3,000

subtotal: $\quad \$ 68,700$

OVBRHEAD

\begin{tabular}{|c|c|c|}
\hline Divialon & Burden $(29.546)^{\circ}$ & 14,800 \\
\hline & Subtotal: & $\$ 83,500$ \\
\hline aneral & Adniniotrative (19.724)* & 16,500 \\
\hline & & $\$ 100,000$ \\
\hline
\end{tabular}

Indrect rates for $\mathrm{FY} 85$ and beyond are provisional and eubject to change ponding RST approval. 


\section{NATIONAL CENTER FOR ATMOSPHERIC RESEARCH}

P.O. Box 3000 - Boulder, Colorado $80307-3000$

Telephont (303) 497-1000 • Telex $45694 \cdot$ - 75: 320-1000

\section{September 1984}

Dr. Michael C. Maceracken

Atmospheric and Geophysical

sciences Division

Lawence Ltvermore National

Laboratory

P. O. Box 80B

Lvermore, a 94550

Dear Make:

I an replyting to your request for a progreas report on the 7494 NCAR effort supported by Larrence Uvernore. The proposed work wa deated to ba: Mdditional work relevant to the nuclear gake quaston w1l bagin in Fra4 on Including a combination FBL paranterization and enhance wreace phyalcs packige in the col so that datalled time and apace evolution of surface tepperature can be reasonably trusted."

To date, I have developed the required linkage mods for a first attempt at carrying out the proponed lork, wth the help of a resenceh asststant, Pat rennedy. All obvious buge have been rewoved with some help from S. Thopson, and w are is the procent of developing longer (20-60 day) simulation to look for more subtle buge or evidence of undesirable features. This wil require compting difference plota batween standard model control nus and nev version simulation, and is boing carried out in collaboration dth 5 . Thoupron. This phase is expected to be completed by the ond of the calendar year.

other related actiolties expected to be pursued in the next tow wonth are to dovelop an annual cyele capability, to add further model layers to beter resolve the FaL and to 1porove the noy rather poor nodel date bue for land surface type prescription. Neurally, meh of the is co-nupported by our ongoing progran.

Youse,

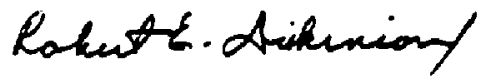

Robert B. Dickineon

cc: S. Schnelder 


\section{NATIONAL CENTER FOR ATMOSTHERIC RESEARCH \\ P.O. Box 3000 • Boulder. Colorado 80307.3000

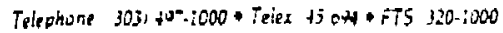

\section{Yarch 1985}

Dr. 'tichael Maccracken

Acea Sanager, Cl imate

Lowrence Livernore National

Laboratory

Mail Stop $L-262$

$30 \times 800$

Livermore, a 94550

Dear M1ke:

This is a letter report on progress made on the profect. "A continuation of Reseasch on Gimatic Bteces of huclear har." carried out by WCAR with support fran LLNL.

Fe proposed work in tive areas. Progress is as follows:

1. Planetary boundary layes, surface processen, diurnal eycle

Yost aspects of out olanned treationt have now been incorporated into the $\operatorname{CO}$ and extensively tested, including a sovon-month annual cycle simulation from January to July. Still being impl mentet is incorpozation of a global data set for solls hydrological and albedo properties. This agpeet is now buing tone with the help of Maureen Wilson, ASP sostdoc, and Ann Benderson-Sellors, AkP visicor. Wh then plan to Establish a five-year (tive annual sycles) control cun and carty sut several sengitivity gtudies, sone invelving nucleat wiuter scenarios.

Jith some further yrograming assistance, these now packages could be made available to other users within a year's time.

2. Subgrij-gcale clmulus convective par aneterizatlons

Donner centinues to work on this topic. Further datails will be given in my next report.

3. Large-seale molsture transport par meterizatlons

Rasch has tested several alternative numerical schemes, but none has yet proved suparior to the standard treatment.

4. Docunentation of the radiation

Progress on this task has bsen Jelayed because Rananathan has developed a new inproved version of the radiation code that will probably be incorporated into future versions of the $\mathrm{CO}$. 
Dr. Michael acCracken

? 3ge 2

21 March 1985

5. Inplementation of season cycle

Chervin, 3oville, and Bath rave developed a code to add the seasonal cycle to the standart CCyos. a version of this code, noditied for diurnal cycle and aloedo shanges, is being used for the work described in iren ?.

ther renarks: illlianson has develuped a 12-layer version of CC1OB that essentialiy alininates the deodrutes from thermal enerjy congezvation found in the seandard rodel varslon.

There have been sone conplaints about computer tapes 30 ing to Luib without being returned. Purchasing replacenents out of the grant seens to be a posisible solution if it is inconventent for the tapes to be recurned from Livertore.

If you have any fugther questions, olease call.

Yours,<smiles>CCC(C)CC(C)CC</smiles>

Robert $\Xi$. Dickinson

sc: R. Anthes

S. Senteider

s. Thompson

ग. Nilitanson 
FCAR Propoeal No. 84-4.2

\author{
A FURTEER CONTLNOATION \\ or \\ RESEARCE ON CLMATIC EFTECTS \\ OR \\ MUCLEAR WAR
}

CCM ENAANCENEAT"

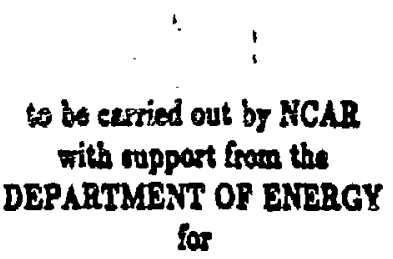

LAWRENCE LIVRMORE NATIONAL LABORATORY

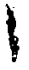

Prineigal Invetizatan:

Robert E. Diclinson

and

Stophen I. Schaeider

Auguet 1035 
CCM ENHANCEMENT

As an update of NCAR proponals \#84-4 and \#B4-1.1 usbmitted in January 84 and Auguat 81, this letter deceribe the proposed FY86 effort that NCAR is uking Lewrence Livermore National Labosatory (LLNL) for suppost to apeed up the development of the Community Climete Model (CCM) parameterisations seeded to improve projections of the climatic effects of auclear was. The propoued work is to be carried out within the Atmoapherie Analysis and Prediction and Adranced Study Divinions of NCAR. A related grent from the Defenue Nuelear Agency, in NCAR'o Advaneed Study Progrum, will be supporting related studies of the elimstic effects of nuclear was.

The work proposed here continue to be only a amall fruction of NCAR's total fofort devoted to improving the CCM and to studying the climatic effects of nuelens war. Bowever, it hould contribute signifenntly to both objective. We are already committed to making available to the general community of CCM wers model impsovements in phyaica and code atructure after they bave been adeguately teated and studied by their originaton. Through collebosative work and clone communication, LLNL ecientists are and will be among the first of outside users to obtain improvements that would ineresse our confideace in simulatione of elimate change seulting from auclear war.

A virtual IBM mechine has been et up at NCAR to expedite code communications with LLNL. Code that will be available upon requeat to LLNL by FY86 includes an energy and mointuse conservative vertical difference scheme dereloped by David Williamson, a vingle ecattering fut arocol code developed by Sturley Thompeon, and a negative moisture fix, diecuned in item 3 below. Many further improvements beins dereloped over the next yeur we being terted in a 12-tixyer "CCMOC" verion of the model which may not be publieally released. Listings of such modifieations can be given to LLiR scientists upon 
request, if they want to attempt their integration into their CCMOB code. Otherwire, we anticipate that the first lurge augmentation to LLNL's code will oceur when a CCMI package is relened in about a year's time. This code will include inprovements developed under contract oupport.

The following in a description of ane tukn, pernonnel, and proponed budget for the FY86 effort at NCAR that Lewrenee Liverwose in being acked to oupport and also summarize propreas and results obtrined under the FY85 proposal. We will provide brief letter seports on sbout a fous: month beis after the requested fund heve been provided to NCAR.

1. Planetery boundary hyor, nuface procenes, and implementatlon of a dibral cjclo (cantinues TYas proposed wark) (R. Dlekinean and P. Itenned)

A simple vertical difiusion depending on Richerden number hus teated and found to be unatable when extended above $500 \mathrm{mb}$. This ucheme provides a utifuetory normal PBL but cannot yet be uned for above amoke cloud convection of nueleur winter seenario. The cause of thin inatability will be identified and Axed. Computer code for a diurnal cycle ha been meshed with the existing radiation package. With auintence from Musreen Wibon and Ann Hendesson-Sellen, we have incosposated into the CCM land ure and woils dete sete required by the surface phynica purameterizations.

All these modifientions of the model dereloped over the last year bave been teated by a rimulation over three revenal cycla. This simulation will bo analyed in deteil; bat pro liminary examination indicate that: (A) the model atmouphere ronal mean elimatolos is quite good, signifleantly improved ores the atundard CCMOB model; (b) the aurface temperatures look quite good in low to middle latituden; and (c) in high latitudes, ourfuce kemperatures are too cold in winter, and Northern Bemisphere bigh latitude surfuce tempesatures are too warm in summer. The winter high latitude problem is probably montly a realt of the unrealintic model bumiditien renulting in a ahortage of cloudn. Fixes developed under item 3 below will be terted to see if this is the ence. The excen summer temperature 
is in part alo a result of deficit in cloudines. In addition, the model is too warm becaure of lack of a permifrout melting beat oink and neglect of poorly drained and amampy land. These feature will be added. We are budgeting a trip for Ann Bendensoa-Sellen from England for aummer 1980 to help pusisu these and other aurface phynica related problems.

2. Subgrld-sealo cumulu cantection parameterisatjon (L. Danner)

Kuo-lype cumulu parameterizations have been developed and teated in the CCM for climate aimulations and are jeing tented in a shost-range forecunt mode. These parmeterization provide entimate of the vertical redistribution of beat and mointure. These pusweterisations at present comewhat degrsde the model climatology. The quention $a$ to whether tain is caused by the parameterizations themselves or other model problems will be explosed.

\section{Largerede molsture trawapart parameterination (P. Pach)}

Ode of the serious current defects in the CCM is its treatment of water rapos, upocielly in high latitudes where, in opite of mavive "filling," large regioss of negative mixins ratics are atill obtained. $A$ number of different transport schemes besides that now being ured but in the model spectral framework have been incorporated into the CCM and teated. None gave any improved realts. Schemes outuide the opectral framework will nor be examined.

The moat sueceuful "fix" of the bigh latitude humidity problem developed so for is a global Glling scheme, which mates bigh latitude humidities more renlintic and warms Junary temperatures by about $5^{\circ}$. This scheme will be tested in the sesuonal cycle surface phyoics model. This code can aloo be released to ILNL ataf upos requeat.

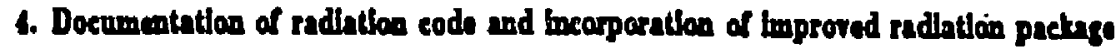
thto CCM1 (J. Thehl)

Ore of the most difieult upects of the CCM for outride usess to wort with is the radiation and eloud aubroutines. These are vary complex and not coded in a form compatible with the seat of the code. Recoding of the exinting routine into the atsadard CCM form is 
not now poesible bectuse of lack of cade documentation. $A$ draft ces of notes documenting the radiation code ba been completed a a necessery prelizic ary atep before improved to diation parameterisations cen be developed and provided to outside wen and is enelosed. A new radiation acheme developed by Ramanathan is now being teated and will becorate part of the asxt frosen model verrion, CCM1, expected to be available in obout a yen's time. Further documentation efitios will be disected toward this code.

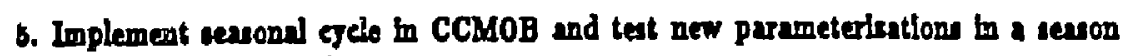
Gcle modo (tauk completed to 2988)

The now standerd supported CCM version (CCMOB) is only et up to do either perpetual January or July simulations. For most climate atudies, newonal cycle simulations

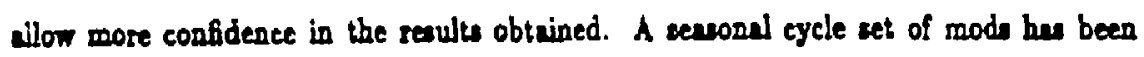
developed ineluding modifications in the radiation routine and organization of date rets for sea ice, oceun auface temperature, and orone path lengths. There are avilable to LLNL ataff upon requeat. 


\author{
BUDGET \\ I Oetotar 1935 thru 30 Septomber 1986
}

$\times$ Effort

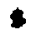

GALARIES,
R. Dickinson
D. 25
L. Donnar
8. 20
P. Konnedy
0. 10
J. Kionl
0.20
P. Raseh
0.20
D. Williamson
0.10
- 16,100
6,200
3,700
6,600
6,100
5,300
Subtotalsi $\overline{i .05}$
$-\overline{43,} \overline{9} \overline{0}$

BENEF I TS (24.5*):

10,800

Subtotaly

.$\overline{54,700}$

MATEAIALS + SUPPLIES,

188

PISRCHASED SERVICES (post age,

communications, masscomp, etc.)

10,090

TRAVEL, I

6,000

Subtorel:

$-79,800$

\title{
QVERHEAD:
}

Division Burdan $(19.64 x)$ :

13,900

Subtotal:

- 84,700

Goneral Admindstrative $(18.01 x)=1$

15,309

TOTAL ।

\$. 00,000

IIndiract rates for FYBS and beyond are provistonal and subject to change pending NSF approval. 


\title{
NATIONAL CENTER POR ATMOSPHERIC REOEARCH

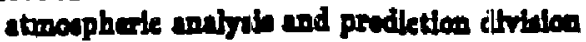

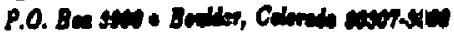

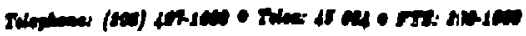

25 Oetober 1998

\author{
Dr. Miehned C. MecCrecken \\ Deputy Divinion Leader \\ Atmoupheric and Geophytieal \\ Scismeen Dirition \\ Lavrecee Liverwore National Lebeantors \\ P.O. Box 809 \\ Livermore, CA 94650
}

\section{Dear Mike:}

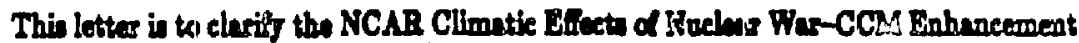

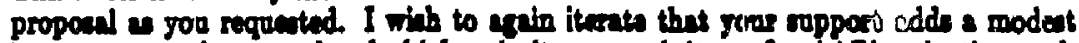

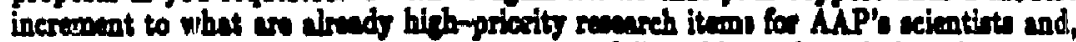

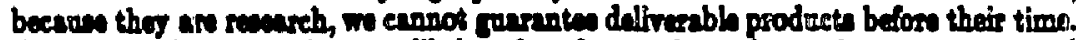

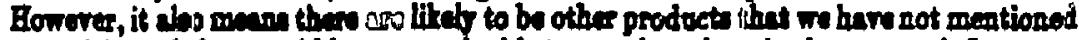

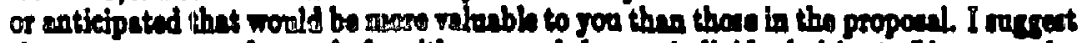

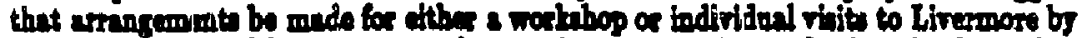

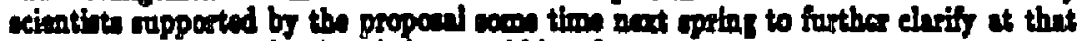

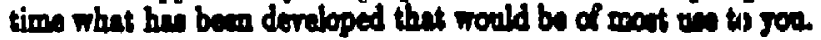

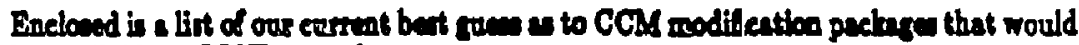
be arilable to LLNL ove the aces yes.

In repones to your quation, an ocenn minod-hye model ben not been developed for the rupposted CCMCO bat is copected to be in the nert you. I have added the

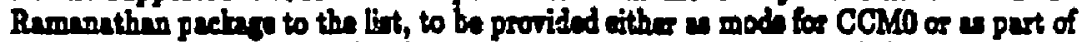

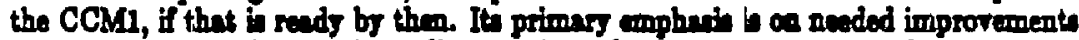

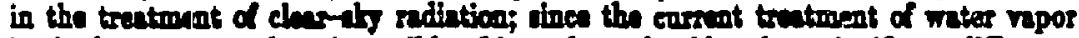
in the lower atratorphese is terribie, this pactages should ralke a vimificant difference

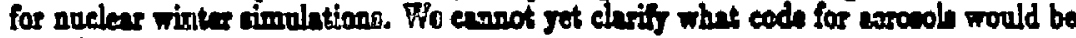
included.

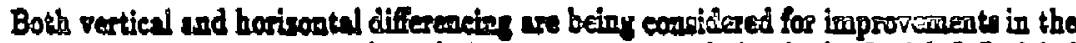

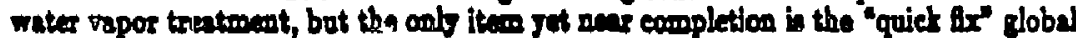

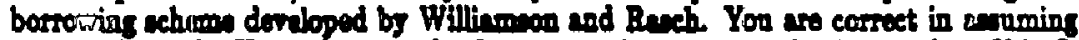

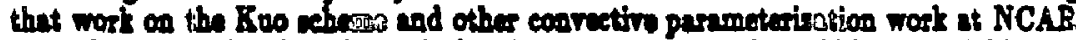

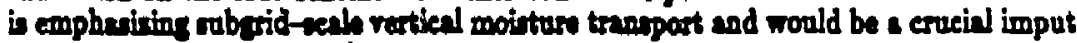
to any future rearniting scheome.

Let me know if you hare any further queotions.

Youn,

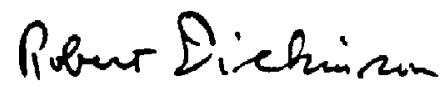

Enclorure

Robert E. Dickineon 


\section{CCM MODIFICATION PACKAGES EXPECTED}

\section{TO BE AVAILABLE FOR LLNL}

\section{DURTNG FY-86}

1. Currently avilable modiffeations

Q. Williamson enerog-conserving rertical differencing scheren.

b. Seasonal cycle with preacribed SST.

c. Fagt, single-acatter serosol solar radiation pactuge.

2. Expected to be available by April, 1980.

a. Preliminary vernion of PBL, rertical diffunion pactage plu moda to add, diunal cycle of radiation.

b. Global flling Ax for negative water vapor mixing ration.

3. Expected to be arailable before October, 1986.

a. Update, if needed, of item $2 \mathrm{~L}$.

b. Preliminary realintic treatment of surface phynica procesen.

c. Ramanathan radiation package.

d. Large-acale horizontal and vertical moisture flux differencing acheme.

e. Mixed-layer ocean.

f. Draft documentation fot 20 and $3 b$. 


\title{
NATIONAL CENTER FOR ATMOSPHERIC RESEARCH \\ P.O. Box 3000 • Boulder, Colorado $80307-3000$ \\ Telephone: (303) 497.1000 • Telar: 45694 • FTS: $320-1000$ \\ 2 May 1986
}

\author{
Dr. Michael C. MacCracken \\ Deputy Division Leader \\ Atmospheric and Geophysical \\ Sciences Division \\ Lawrence Livermore National Laboratory \\ P.O. Box 808 \\ Livermore, Californis 94550
}

\section{Dear Mike,}

To add to $m$ y letter of 25 October 1985, here is a progrese report on where we stand at NCAR with respect to the CCM enhencemento for pursuing research on the effects of nuclear war on the atmosphere. The grant morey for this year is now at NSF and should arrive st NCAR shortly.

I have been worting with Pat Kennedy on the new ouffuce physics pactage and we have carried out several sensitivity studies in collaboration with Hegderson-Sellers and Wilson of the UK. Enclosed are drafts of two manuscripts renulting from this collaboration. A new documentation for this part of the CCM including treatment of soils is being prepared and will be sent to you as soon as possible, probably this summer.

Leo Donner has inveatigated the thermodynamic and dynamic interactions between cumulus convection and large-scale flows. He analyzed the impact on the thermodynamic balance of the NCAR CCM of a version of the Kuo cumulus parameterization scheme and found a strong interaction between cumulus conrection and radiative forcing through cloud feedbacks. This study also suggeoted that excessive cooling and drying of the lower tropical troposphere due to the Kuo scheme required subatantial reformulation of the parameterieation for deep cumulus convection, which is being accomplished through a scheme integrating explicitly over the lifetime of the cumulus ensemble. A parameterization for the generation of large-acale vorticity by cumulus convection has also been developed.

Philip Rasch ha been developing a scheme for ccalur transport using a technique known as Flux Correted Tranport (FCT), for integration into the CCM. FCT is a hybrid scheme which combines solutions found by a high and low eccuracy technique in a fashion designed to exploit the beet characteristies of both. Eurly implementations of FCT were done in a Curtesian geometry on an equidistant grid, or using a one-dimensional framewort with time splitting to handle multi-dimenuional problezs. Here, FCT is being extended to make FCT function in a spherical geometry on a non-equidistant (Gaussian) grid. Spectral and Donor Cell technique have been used for the high and low accuracy parto respectively. The scheme has been implenented in simple test-bed, a continuity equation on the sphere with a nondivergent velocity feld which advects the scalar across the poles. The scheme shows promise in this setting but the opherical coordinates have a singularity at the poles which result in significant problems there for almost any scheme, requiring great care to be taken. The latest results with FCT are encouraging, but it is not yet clear whether all the problems are resolved. 
J. T. Kiehl has been working on restructuring all of the radiation routines in the CCM. In the process of this code restructuring, both internal and external documentation are being added to the CCM. The present status of this work is that the radiation part of the CCM has now been separated into shorter and more readable subroutines. Within each of these subroutines, internal documentation including references to published works describing the physical parameterizations has been added. Notes on the numerical algorithms used to solve the radiative transfer equation have also been added to each subroutine. The final phase of the code restructuring will be external documentation of the radiation code. This will be completed within the next two months, and will appeas in the form of an NCAR technical note. The purpose of the external documentation will be to provide users a description of the physical parameterizations used in the radiation routines.

Dave Williamson has been occupied with finalizing the code for $\mathrm{CCM}$, which includes several of the improvements 1 developed earlier such as local Richardson number dependent vertical diffusion and diumal cycle. As soon as a file is available, we will start incorporating our surface package into CCM1. We expect the NCAR computing environment to remain poor until October because of major disruptions related to in. stallation of a CRAY X-MP. Considerable effort has been required over the last three months in maintenance of codes and date sets in a hostile environment. We expeet to be sble to provide you with the new CCMI by next October, and the surfoce pactonge coupled to it, shortly thereafter. Preliminary codea could be provided earlier if you have a need for them.

Yours,

$$
\text { Bus }
$$

Robert E. Dickinson

RED/hrh

Enclosures 


\section{NATIONAL CENTER FOR ATMOSPHERIC RESEARCH \\ P.O. Box 3000 - Boulder, Coloradu 80307-3000 \\ Talephone: (303) 497-1000 - Teles: 45694 - FT5: 320-1000}

3 December 1986

Dr. Michael C. MacCracken

Area Manager, Climate

Lawrence Livermore National Laboratory

Mail Stop L-262

Box 808

Livermore, CA 94550

\section{Dear Mike:}

This letter is intended to represent the final report for the grant to NCAR from Lawrence Livermore National Loboratory to support work of the NCAR Community Climate Model. It updates the previous 2 May 1986 report and indicates further materials to be delivered when availsble.

The new surface pactage (BATS) has been documented through in-code comments and 8 detuiled technical note (Ref. 1). The technical note is in press, and several copies will be mailed as part of this report as soon as available (by January 1987). An ofiline version of the current code is available to you upon request. The version running with CCMO is not maintained, but efforts are now devoted to completing conversion to the new CCM1. We expect this task to be complete in about two months, after which the CCM1 appropriate code, including diurnal cycle, can be sant you upon request (this includes the offline version).

Worls by Leo Donner on the cumulus parameterisation in the CCM (Ref. 3), partially supported by the grant, will appear in the 1 November 1986 issue of The Journal of the Atmospheric Seiences, and reprints will be forwarded when ready.

The efforts by Philip Rasch to use a Flux Corrected Transport technique for scalar transport in the CCM revealed severe difficultic of the poles, and the work was abandoned.

J.T. Kiehl has continued to work on improving the radiation routines in the CCM. These efforts have been incorporated into the new CCM1 code and its supporting documentiation (Ref. 2), the latter still in preparation.

Dave Williamson is almost frished finalizing the CCM1 code and expects to have a code description (Ref. 2) and all other documentation complete in time for the CCM external Advisory Committee at the end of Jonuary. The code files for CCM1 should be frozen within the next month, after which they can be supplied to you upon requedt.

Yourt,<smiles>[Te][Te]</smiles>

Enclosur:

Robert E. Dickinson 


\section{DOCUMENTATION TO BE SENT LATER}

1. Dickinson, R. E., A. Henderson-Sellers, P. J. Kennedy, and M. F. Wilson, 1986: Biosphere-Almosphere Transfer Scheme (BATS) for the NCAR Community Climate Model. NCAR Technical Note, National Center for Atmospheric Research, Boulder, Colorado, in press.

2. Williamson, D. L., J. T. Kiehl, V. Ramanathan, and R. E. Dickinson, 1987: Deseription of NCAR Community Climate Model (CCMI). NCAR Technical Note, National Center for Atmospheric Research, Boulder, Colorado, in preparation.

3. Donner, L.J., 1986: The sensitivity of the thermal balance in a general circulation model to a parameterization for cumulus convection with radiatively interactive clouds. Journal of the Atmospheric Sciences, in press, November 1986. 


\section{List of Publications and Reports'}

Dickinson, R.E., A. Henderson-Sellero, 2.J. Kennedy, and M.F. Wilson, 1988: BiosphereAtmosphefe Tranofer Scheme (BATS) for the NCAR Community Climate Model. NCAR Technical Note, National Center for Atmospheric Research, Bouider, Colorado, in press.

Williamson, D.L., J.T. Kiehl, V. Ramanathan, and R.E. Dichinson, 1987: Deseription of NCAR Community Climate Model (CCM1). NCAR Technical Note, National Center for Atmospheric Research, Boulder, Colosado, in preparation.

Donner, L.J., 1986: The sensitivity of the thermal balance in a general circulation model to a parameterization of cumules coapection with radiatively interactive clouda. Joumal of the Atmoupherie Sciences, in press, November 1980.

Kiehl, J.T., C. Brihl, and T. Yomenonchi, A parameterisation for the ebeorption doe to the near infrared bands of $\mathrm{CO}_{2}$. Tellus, 97B, 189-190, 1985. 